\title{
A Typology of Dissent in Religion Cases in the Grand Chamber of the European Court of Human Rights
}

\author{
Sophie van Bijsterveld \\ Professor of Religion, Law, and Society, Faculty of Philosophy, Theology, and \\ Religious Studies, Radboud University, Nijmegen, The Netherlands
}

\begin{abstract}
Dissenting opinions in European Court of Human Rights judgments are a familiar phenomenon. Nevertheless, they receive little or no systematic attention. This essay presents a typology of dissenting opinions in religion cases in the Grand Chamber of the European Court. It identifies patterns of dividing lines within Grand Chamber decisions in religion cases and discusses these patterns.
\end{abstract}

\section{Keywords}

European Court of Human Rights (ECtHR) - freedom of religion - Article 9 European Convention of Human Rights (ECHR) - dissenting opinions - human rights constitutional law

\section{$1 \quad$ Introduction}

The 1993 Kokkinakis judgment was the first in which the European Court of Human Rights (hereafter: the European Court, the Court, or the ECtHR) found a violation of Article 9 of the European Convention on Human Rights (hereafter: the Convention or the ECHR), the right that guarantees the freedom of thought, conscience or religion. The judgment was not unanimous. Unlike the Commission before it, the Court was divided. The dictum of violation of Article 9 of the Convention was supported by 6 votes to 3. The Court also held with 8 votes to one that there had been no breach of Article 7 of the Convention. It

(C) SOPHIE VAN BIJSTERVELD, 2017 | DOI 10.1163/18710328-12231159

This is an open access article distributed under the terms of the prevailing CC-BY-NC license at the time of publication. 
was unanimous only in its conclusion that it was unnecessary to consider the case under Article 10 or under Article 10 taken in conjunction with Article 9. ${ }^{1}$

Dissenting opinions in European Court judgments are a familiar phenomenon. The wide-ranging attention that specific religion cases attract in the national and international academic world includes cases with dissenting opinions. Spectacular cases such as the Italian Lautsi concerning the lawfulness of a crucifix in the public class room or the Norwegian Folgerø case that was decided with a vote of $9-8$ are cases in point. ${ }^{2}$

Still, dissenting opinions are one of the features of ECtHR judgments that receive little or no attention as such. This is true for religion cases as well. The lack of interest in dissenting opinions is not surprising. It is the majority that decides the case and the judgment in the case is built around the view of the majority. In the course of time, the Court has developed an elaborate set of 'general principles' that have become part and parcel of its interpretation and understanding of Article 9 and it is these principles that are applied to the particular case. And, as we shall see, it is hard to attribute, at least at first sight, a wider-ranging meaning to a dissenting opinion than merely a dissenting opinion in the particular case.

Nevertheless, dissenting opinions in religion cases of the European Court deserve systematic analysis. A systematic analysis of dissenting opinions helps us to gain a deeper understanding of the reasoning of the majority speaking for the Court. This is all the more so as religion cases increasingly seem to have become controversial issues in states that are party to the Convention. Furthermore, judgments in religion cases by the European Court are often extensively commented on and criticized. It is not always easy to predict an outcome of a case based on knowledge of previous case law and the interpretative principles that the Court has developed in the context of Article 9 of the Convention.

This article presents a typology of dissent in religion cases of the European Court based on a systematic analysis of dissenting opinions. It focuses on Grand Chamber judgments. These judgments are of particular interest as they concern highly contested issues. Judgments of the Chamber-and of the

1 European Court of Human Rights (chamber), Kokkinakis v. Greece, Application No. 14307/88, 25 May 1993 .

2 European Court of Human Rights (Grand Chamber), Folgerø et al. v. Norway, Application No. 15472/02, 29 June 2007; European Court of Human Rights (Grand Chamber); Lautsi v. Italy, Application No. 30814/06, 18 March 2011. 
former Commission - are taken into account in as far as they deviate from the Grand Chamber in their previous judgment or report respectively. ${ }^{3}$

In assessing whether Article 9 of the European Convention has been violated, the European Court follows a consistent line of approach. It consecutively determines whether a complaint falls within the scope of Article 9, and, if so, whether there has been an interference with this right. When this has been affirmed, the Court examines whether the interference is 'prescribed by law', and, if so, whether the state has pursued a legitimate aim. After this last question has also been positively ticked off, the issue remains as to whether the interference is 'necessary in a democratic society'. The Court has developed the so-called doctrine of the 'margin of appreciation. ${ }^{4}$ According to this doctrine, the state is granted a certain room for manoeuvre in making its own assessment whether the contested action was 'necessary'. The Court usually adds that this margin of appreciation 'goes hand in hand with a European supervision embracing both the law and the decisions applying it'. ${ }^{5}$

This approach is not only followed in relation to Article $9 \mathrm{ECHR}$, but also in relation to other Convention articles that are relevant to our analysis, such as the right to respect for private and family life (Article 8), freedom of expression (Article 10) or freedom of assembly and association (Article 11). Article 2 of Protocol 1, which guarantees the right to education, however, has a different structure, and, therefore, does not lend itself to the same approach. ${ }^{6}$ The same

3 For a detailed analysis of dissenting opinions in religion cases in the Grand Chamber, see Sophie van Bijsterveld, 'Dissenting Opinions in Religiezaken voor het Europees Hof (I): De Grote Kamer', 6(3) Tijdschrift voor Religie, Recht en Beleid 2015, pp. 28-48; and, for dissenting opinions in religion cases in the Chamber, see Sophie van Bijsterveld, "Dissenting opinions" in Religiezaken voor het Europees Hof (II): De gewone kamer', 7(1) Tijdschrift voor Religie, Recht en Beleid (2016), pp. 27-58.

4 On the margin of appreciation in religion cases, see the contribution by Stephanie Berry', 'Religious Freedom and the European Court of Human Rights' Two Margins of Appreciation', 12:2-3 Religion and Human Rights (2017), pp. 198-209, this special issue.

5 See, for instance, paragraph 110 of the Grand Chamber judgment in the case Leyla Sahin v. Turkey, Application No. 44774/98, 10 November 2005.

6 On Article 2 of Protocol 1, see the contribution by Jeroen Temperman, Parental Rights in Relation to Denominational Schooling' under the European Convention on Human Rights, 12:2-3 Religion and Human Rights (2017), pp. 142-152, this special issue. 
is true for Article 6, paragraph 1 (right to fair trial), a right that is invoked in religion cases as well.

The first expectation is that that dissenting opinions focus on the question whether an interference is 'necessary in a democratic society'. More specifically, one could expect that the application of the doctrine of the margin of appreciation is a central theme in dissenting opinions; an expectation that is strengthened by the fact that scholarly criticism of the Court's judgments in religion cases regularly criticizes precisely the Court's use of this doctrine. ${ }^{7}$

A complainant may invoke more than one Convention article. In such cases, the European Court deals with the complaint under the most appropriate and relevant article and more than once it concludes that a review under the other article(s) is no longer necessary. It may also be expected that assessments in this connection make up for differences within the Court.

Division may always manifest itself with regard to other issues. However, the aims legitimately to be pursued by states are far-reaching; and, the Court has authoritatively defined the criterion 'prescribed by law'. Because of this, controversy on these issues seems less likely.

\section{$3 \quad$ Analysis: A Typology of Dividing Lines}

Analysis of Grand Chamber decisions in religion cases does not confirm the expectation that a different assessment of the margin of appreciation to be awarded to the state forms the main reason for division within the Court. In none of the Grand Chamber cases studied, did the margin of appreciation as such play a recognizable role in the internal division. Even when mentioned, its role in the actual line of reasoning is not apparent.

However, two other, distinct dividing lines come to the fore. The first is the interpretation of freedom of religion, and related to this, the assessment of relevant facts and the choice of the Convention article under which to review the case. The second dividing line, which is even more distinct, concerns the nature of the review itself. This dividing line can best be designated by

7 See, for instance, Janneke Gerards, 'Pluralism, Deference and the Margin of Appreciation', in 17(1) European Law Journal (2011), pp. 80-120; Jan Kratochvíl, 'The Inflation of the Margin of Appreciation by the European Court of Human Rights', 29(3) Netherlands Quarterly of Human Rights (2011), pp. 324-257; Susan S.M. Edwards, 'No Burqa's We're French! The Wide Margin of Appreciation and the ECtHR Burqa Ruling', 26 Denning Law Journal (2014), pp. 246-260. 
introducing the concepts of abstract and concrete review. ${ }^{8}$ Abstract review takes place when the contested state activity itself is regarded to be in violation with the Convention or not, apart from the circumstances of the case. Concrete review takes place when the specific circumstances of the case are taken into account and are deemed decisive for the final judgment in the case. We will elaborate on this difference more specifically later in this section. We will give an example of each of the categories.

\subsection{Interpretation of Freedom of Religion}

A clear example of interpretation was at stake in the Armenian case of Bayatyan. ${ }^{9}$ The applicant in this case was a Jehovah's Witness. He was drafted for military service. As a result of his refusal to perform military service on the grounds of his religious belief, he was convicted by an appeal court and sentenced to 2,5 years imprisonment. Before the Court, the applicant asserted that his conviction formed an unlawful limitation of his rights under Article 9 of the Convention. The legal issue for the Court was whether refusal of performing compulsory military service fell within the ambit of the rights protected by Article 9. With a 16-1 majority, the Grand Chamber answered the question positively. In doing so, it reversed the judgment of the Chamber. In a 6-1 vote, the Chamber had previously concluded that Article 9 did not stretch to refusal of military service. Thus, the Chamber deliberately followed the line of the former Commission. Nevertheless, it chose to submit the issue to the Grand Chamber, which, in its decision referred to the Convection as a living instrument which must be interpreted in the light of present-day conditions' 10 and took into account the developments in law and practice. The Armenian judge voted with the majority in the Chamber case, and did not change opinion in the Grand Chamber case, a line of approach which was followed in two other chamber cases as well. This is a clear matter of interpretation of the scope of Article 9 of the Convention.

The concepts of abstract and concrete review thus refer to the method of reasoning in the context of a particular case in the ECtHR. These concepts should, therefore, not be confused with the label 'concrete review' for judicial reviews in cases and controversies as opposite to the label 'abstract review' for judicial review in the abstract outside the context of cases and controversies and initiated by another state institution, examples of which can be found in Germany or France.

9 European Court of Human Rights (Grand Chamber), Bayatyan v. Armenia, Application No. 23459/03, 7 July 2011.

$10 \quad$ Ibid., para. 62. 
Genuine matters of interpretation sometimes occur in a context in which slightly broader issues of assessment play a role. Thus, questions of which facts are actually relevant in the light of the Convention article under discussion come into play. A good example of such a case is the French case of Cha'are Shalom. ${ }^{11}$ The Jewish organization Cha'are Shalom was refused a license for ritual slaughter on grounds that it was not representative of the Jewish community in France as such, and that it did not have the required religious entity status under French law. A license, however, was granted to the umbrella organization from which the complainant was an orthodox breakaway. With a $15^{-2}$ majority, the Grand Chamber, to which the case was relinquished, rejected the appeal. It pointed at the fact that the difference between the two organizations did not concern the method of slaughtering in the strict sense, but 'merely' the intensity of inspection afterwards of the slaughtered animal. According to the Grand Chamber Article 9 would be interfered with only in case it would be impossible for ultra-orthodox Jews to obtain the desired meat, such as through import or specifically labelled meat from France. In the slipstream of this reasoning, it also concluded that Article 14 taken in conjunction with Article 9 ECHR was not violated. A minority of seven judges did conclude that Article 9 was violated. A previously granted license did not dismiss the Court from carefully examining a license request from an applicant within the same religion. The matter of whether the meat could be obtained otherwise, was not deemed relevant. In the view of the minority, the real problem was the unequal treatment of the organization in relation to the other one, therefore an issue under Article 14 taken in conjunction with Article 9. Its assessment of the case under these articles also led to the conclusion of violation.

\subsection{Abstract versus Concrete Review}

The French S.A.S. case is a Grand Chamber case in which the divergence between the majority and the minority judgment hinged on the nature of the review. ${ }^{12}$ The majority of the judges reviewed the case in an abstract way. The dissenting judges carried out a concrete review. The latter even explicitly criticized the majority on their approach to reviewing the case.

The S.A.S. case concerned a complaint by an Islamic woman. She alleged that the prohibition to conceal one's face in public places violated amongst other things her rights under Articles 8, 9 and 10 taken separately and together

\footnotetext{
11 European Court of Human Rights (Grand Chamber), Cha'are Shalom Ve Tsedek v. France, Application No. 27417/95, 27 June 2000.

12 European Court of Human Rights (Grand Chamber), S.A.S. v. France, Application No. 43835/11, 1 July 2014.
} 
with Article 14 of the Convention, as it made it unlawful for her as a Muslim to wear the burqa and the niqab. She explicitly stated that she wore these out of her own free will, both in private and public, although not at all times; she also stated that she was willing to show her face for specific purposes, such as identification.

With a $15^{-2}$ vote, the Grand Chamber dismissed the claims of violation of Articles 8 and 9; it unanimously held that there had been no violation of Article 14 taken together with these articles; likewise, it held unanimously that no separate issues arose under Article 10. Finding its starting point in the aim of the French state to "guarantee the conditions of "living together" 13 the Grand Chamber found the broad ban proportionate. It stated that the law did not 'affect the freedom to wear in public any garment or item of clothingwith or without a religious connotation-which does not have the effect of concealing the face. ${ }^{14}$ It also pointed to the fact that the criminal sanctions were 'among the lightest that could be envisaged'. ${ }^{15}$ And after paraphrasing the French state's objective to 'protect a principle of interaction between individuals, which in its view is essential for the expression not only of pluralism, but also of tolerance and broadmindedness without which there is no democratic society,' ${ }^{16}$ it concluded that the introduction of a ban such as the contested one was 'a choice of society'.17

The two joint partly dissenting judges not only criticized the justification of the aim of 'living together' under the Convention, they also rejected the 'sacrificing of individual rights to abstract principles.' ${ }^{18}$

\section{4}

\section{Discussion}

Awareness of the nature of the dividing lines within the Grand Chamber helps us gain a deeper understanding of Grand Chamber judgments. This is true for both divided and unanimous judgments. Likewise, it helps us in valuing Chamber judgments. Such understanding is all the more relevant as the actual argumentation of European Court judgments in religion cases often leaves

\footnotetext{
13 Ibid., para. 142.

14 Ibid., para. 151.

15 Ibid., para. $15^{2}$.

16 Ibid., para. 153 .

17 Ibid., para. 153 .

18 Dissenting opinion, para. 2.
} 
room for question. Insight into the patterns of dividing lines, provides a more direct grip on the actual handling of a case by the Court.

Analysis of dissenting opinions in the context of Grand Chamber judgments in religion cases shows us that difference in view can hinge on the interpretation of Article 9 of the Convention and, related to that, the choice of the viewpoint from which to assess the case. The choice of viewpoint concerns the choice of which right is most appropriate for reviewing the case under and the assessment which precise facts are relevant for this review.

Interpretation of Article 9 of the Convention in terms of defining its scope may involve clear-cut legal politics. Such was the case in accepting that a refusal of compulsory military service was protected by Article 9 of the Convention. Such explicit issues are usually not involved, but rather the question which facts of the case are most relevant to the Court's review and which article of the Convention is primarily relevant for this review. These issues that arise are closely connected to the case itself and are important in themselves; they do not lend themselves well for a more general analysis. It remains remarkable, however, that at such a high level of judicial judgment, such fundamental differences exist about the relevant facts and the perspective from which to deal with a case, also in the light of a quarter century of tradition in religion cases in the Court.

The most interesting difference in approach is that between concrete and abstract review. It manifests itself quite regularly, although the number of Grand Chamber cases is too small to draw further-reaching conclusions about its occurrence. When the European Court is called to decide whether a violation of Article 9 of the Convention, or a similarly structured right, has been violated, one of the successive questions the European Court needs to answer is whether an infringement by law that serves a legitimate purpose is 'necessary in a democratic society'. It is within the context of this criterion that choice between abstract or concrete review is made.

Is the use of abstract review an instrument used the majority or minority in religion cases? And what about concrete review? On the basis of the analysis of Grand Chamber cases, these questions cannot be answered. The majority may resort to abstract review but so does a minority. The same is true for concrete review.

The question may be asked whether the use of abstract or concrete review in religion cases has any predictive value in terms of finding a violation of a Convention right. The answer is negative. Such predictive value cannot be established.

Does the latter change when we look at the material outcome of the case? The answer is negative again. Abstract review may be detrimental for the case 
of religion, but it may also be beneficial to religion or the church. The same is true for concrete review.

We started with the expectation that the doctrine of the margin of appreciation would play a significant role in dividing lines between the majority judgment and minority opinions in religion cases. Now we have detected a difference between concrete and abstract review as a prominent dividing line, the following question presents itself. How does the dividing between concrete and abstract review relate to the margin of appreciation? Can we say for example that concrete review leads to less of a margin of appreciation for the state, something one might expect? The answer is negative. Both concrete and abstract review can produce a result that provides the state ample room for manoeuvre.

\section{$5 \quad$ Conclusion}

The expectation with which this analysis of dissenting opinions in religion cases in the Grand Chamber began, was that the dividing lines could predominantly be found in the assessment of whether an interference of the invoked Convention right(s) would be 'necessary in a democratic society'. In this context, it was anticipated that the focus of this assessment would be the degree by which a state was to be granted a 'margin of appreciation'.

The analysis of dissenting opinions in Grand Chamber religion cases shows that the application of the doctrine of the margin of appreciation remain ever so hard to get a grip on. A wider margin of appreciation is likely in situations in which considerable differences exist between Member State with regard to the national legal arrangements concerning the issue in question; and, in situations in which a high level of controversy on issues like the one in question exists in Member States. Apart from these very general notions, it is hardly possible to get 'closer' to this concept. Even then, it seems that the concept 'margin of appreciation' can better be seen in terms of the outcome of a judgment, rather than a method of reasoning or an argument that plays an identifiable role in a clear weighing process.

However, patterns of dividing lines do exist. One dividing line concerns the interpretation of Article 9 of the Convention, and, related to this, the choice which facts of the case are relevant for reviewing the case. In a way, this is surprising as one might think that 25 years after Kokkinakis and with the Grand Chamber itself close to its 2oth anniversary, such issues would by and large have been settled. 
The second dividing line, and a prominent one at the same time, can best be characterized by labelling the differences in approach as abstract versus concrete review. The application of one or the other approach in the Grand Chamber religion cases led to different outcomes in the particular case. However, applying one or the other approach in general has no predictive value as to the outcome. Neither has it a predictive value as regards the material position of religion, nor does it point to a wider or more narrow margin of appreciation. The conclusion that we must draw then is that the application of concrete or abstract review is an instrument in a particular case to reach a particular, desired outcome in that case. Of course, it is for the outsider not possible to know whether these types of review are used this way by the judges.

What does this result in? The possibility of delivering a dissenting opinion fosters the visibility of the dialogues within the European Court. Another conclusion may be that cases that reach the Grand Chamber after first been through all the national judicial stages are simply: difficult cases. 